\title{
Operetta As Safe Space
}

Kevin Clarke

Raziskovalni center za opereto v Amsterdamu

The Operetta Research Center Amsterdam

\section{Triggering Contemporary Operetta Research}

The illusion of the 'safe space' is a symptom of globalization: right wing as well as left wing groups, Muslim fundamentalists, and others, they all long for cleaned-up rooms in which nothing foreign can disturb them. [...] Not only in the US, UK, and Canada do we find fundamentalist (religious) communities at universities that demand 'safe spaces,' protected spaces that are called 'positive spaces' now: there, they want to be shielded from unwanted encounters with texts, thoughts, and people, for example via advance 'trigger warnings.' [...] Labels such as 'heimat' and 'safe space' counter globalization with comfortable miniature worlds in which no one needs to be afraid of the intrusion of alien aspects.

That's how journalist Caroline Fetscher describes the 'phantasm of a purified space' in the Berlin-based newspaper Der Tagesspiegel in May

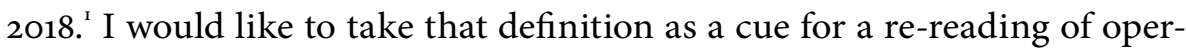

1 'Die Fantasie der 'Safe Spaces' ist ein Symptom der Globalisierung: Viele Rechte, Linke, Islamisten und andere wünschen sich bereinigte Räume, in denen nichts Fremdes stört. [...] Nicht nur in den USA, Großbritannien und Kanada gibt es an Universitäten sowie in fundamentalistisch religiösen Communities Forderungen nach 'safe spaces', nach geschützten Räumen, inzwischen auch 'positive spaces' genannt. Dort soll man vor der Begegnung mit unerwünschten Texten, Gedanken oder Personen bewahrt werden, etwa durch 'Trigger-Warnungen' von Lehrenden, die auf krude Passagen in Shakespeare-Dramen vorab aufmerksam machen sollen. [...] 'Safe Spaces' 
etta history in this essay and ask: were operettas ever safe spaces that shielded groups from alien intrusion? Were operetta theaters ever 'cleaned up' venues where audiences and artists enjoyed themselves without being disturbed by opposing moral or religious values? Were operetta theaters and the shows performed there 'positive spaces'? And what about triggers in operetta, not just in times of iTunes where titles are marked as 'clean' or 'explicit' to prevent unwanted encounters with supposedly 'dirty' content?

To meditate on this, I will follow the development of opéra bouffe and early operetta from the 1850 s to the present day in chronological order. And I will ask what exactly drew audiences at different times to the genre commonly known as operetta today, and why it is important to keep their different motivations for associating with operetta in mind when evaluating this particular form of musical theater. Because one person's idea of operetta, at any given moment, might not be someone else's, yet both will have good reason to believe that their definition of the genre is historically correct.

In her 2012 study Das deutschsprachige Operettenlibretto: Figuren, Stoffe, Dramaturgie author Heike Quissek comes to the following definition of the genre, after 290 pages of analysis:

As a text the operetta libretto is a plural-media work of art (plurimediales Kunstwerk). [...] For the reception of an operetta it is essential to consider its presentation: which staging and casting effects are utilized, which external comic elements are added and what (grotesque) dancing in combination with dialogue and music is added? Together these elements define the visual catchiness that determines the pulling power of an operetta. As a result, operetta is a theatrical art form whose basis is the stage representation. [...] The exchange and interchange with other 'social institutions' - such as the theaters in which operettas are performed, censorship offices, the press etc. - are more important in defining what operetta is than in any other text-based genre. So, in order to demarcate and sind die zentrale, modellhafte Metapher für Reaktionen auf die Überforderung durch expandierenden Pluralismus. [...] Begriffe wie 'Heimat' und 'Safe Spaces' setzen der Globalisierung trauliche Miniaturwelten entgegen, in denen man, gleichsam von der Wiege eines idyllischen Zuhause geschaukelt, keine Furcht haben muss vor dem Einbruch vermeintlich fremder Phänomene ins vermeintlich Alleineigene: reiner Raum." - Caroline Fetscher, "Das Phantasma des reinen Raums," Tagesspiegel, May 8, 2018, https://www.tagesspiegel.de/politik/angst-vor-der-globalisierung-das-phantasmades-reinen-raums/21258152.html. 
define the genre, we need to take the types of production and institutions into consideration. Only then can we differentiate operetta from other musical and literary genres. In the end, everything has to be counted as operetta that was called thus by the authors and that was performed as operetta in respective theaters. ${ }^{2}$

Obviously, that's a rather vague characterization that says: anything can be performed as operetta, but also operettas can be performed as anything else, for example as opera and musical comedy. The dividing lines seem blurry. The defining elements are, according to Quissek: (1) type of performance, (2) type of cast, and (3) expectations of the audience. I would like to take these three elements as guidelines for the following survey.

\section{Operetta Theaters As Brothels}

In his novel Nana, describing the operetta situation in Paris in the 186os, Émile Zola has the director of the Théâtre des Variétés say on the third page of the book that his "theater" is a "brothel." Of course the Théatre des Variétés is the place where many famous Offenbach pieces premiered, among them La belle Hélène (1864), La Grande-Duchesse de Gérolstein (1867) and La Périchole (1868), all starring Hortense Schneider who served Zola as a role model for his heroine. In her book Grandes Horizontales: The Lives and Legends of Four Nineteenth-Century Courtesans, Virginia Rounding writes in 2003:

The backbone of the French system was the registration of prostitutes, a registration which could be entered into voluntarily or en-

2 "Als Text ist das Operettenlibretto Teil eines plurimedialen Kunstwerks. [...] Bei der Rezeption einer Operette [erweist sich] die Notwendigkeit der Bühnendarstellung als ungleich zwingender und bedeutender: Entsprechende Spieleffekte, suprasegentale Komikelemente und (komisch-grotesker) Tanz in Verbindung mit Dialog und Musik können nur in der visuellen Faßbarkeit ihre Bühnenwirksamkeit entwickeln. Die Operette ist demgemäß eine Bühnenkunst, die ihre Substanz vor allem aus der Darstellung bezieht [....]. Ihren Wechselbeziehungen zu 'anderen sozialen Institutionen (zum Theater, indem die Werke aufgeführt werden; zur Zensurbehörde; zur periodischen Presse etc.)' kommen somit tendenziell größere Bedeutung zu als dies bei anderen literarischen Gattungen der Fall ist. Begreiflicherweise ist es daher angebracht, die Gattung zu allererst über Inszenierungstypen bzw. Institutionen gegenüber anderen musikoliterarischen, zeitgenössischen Gattungen abzugrenzen und zu definieren: All das hat als Operette zu gelten, was die Autoren so bezeichnet wissen wollten und was an den entsprechenden Theatern als solche aufgeführt wird." - Heike Quissek, Das deutschsprachige Operettenlibretto: Figuren, Stoffe, Dramaturgie (Stuttgart, Weimar: J. B. Metzler 2012), 293. 
forced following an arrest. [...] Prostitutes were forbidden to solicit or even appear in the street or other public places before seven o'clock in the evening and after ten or eleven at night. Neither were they supposed to draw attention to their trade by dressing or behaving provocatively. ${ }^{3}$

This situation makes it understandable why prostitutes, and those who wanted to meet them, preferred to camouflage their business as 'theater' and move it to a safe space behind closed doors.

Zola received first-hand information about the Théâtre des Variétés from Ludovic Halévy, Offenbach's brilliant librettist. Halévy took Zola backstage and showed him the dressing-room where in 1867 Hortense Schneider had ceremoniously received the young Prince of Wales. That, as well as many other 'juicy' stories, found their way into Nana. ${ }^{4}$

The idea of theater as brothel and actresses/actors as prostitutes is not new. "Acting, exhibiting one's body to the public, has been equated with prostitution from the earliest records of performance," writes Laurence Senelick in his essay "Sexuality and Gender" in 2018 in The Cultural History of Theatre in the Age of Empire. "The performer's physical availability may be hedged round with religious or ritual atavisms, but he and particularly she are subject to the desires and appetites of the spectator."'

About these 'appetites' we read in Zola's novel, in the context of the first appearance of Nana as a blonde Venus:

A shiver went round the house. Nana was naked, flaunting her nakedness with a cool audacity, sure of the sovereign power of her flesh. [...] Her Amazon breasts, the rosy points of which stood up as stiff and straight as spears, could be [...] clearly discerned [...] beneath the filmy fabric. [...] And when Nana raised her arms, the golden hairs in her arm-pits could be seen in the glare of the footlights. [...] The men's faces were tense and serious, their nostrils narrowed [...]. All of a sudden, [...] the woman stood revealed, a disturbing woteenth-Century Courtesans (London: Bloomsbury, 2003), $11 \mathrm{ff}$. Émile Zola, Nana, trans. George Holden (London: Penguin Classics 1972), 21. the Age of Empire, ed. Peter Marx (London, Oxford, New York, New Delhi, Sydney: Bloomsbury, 2018), 77. 


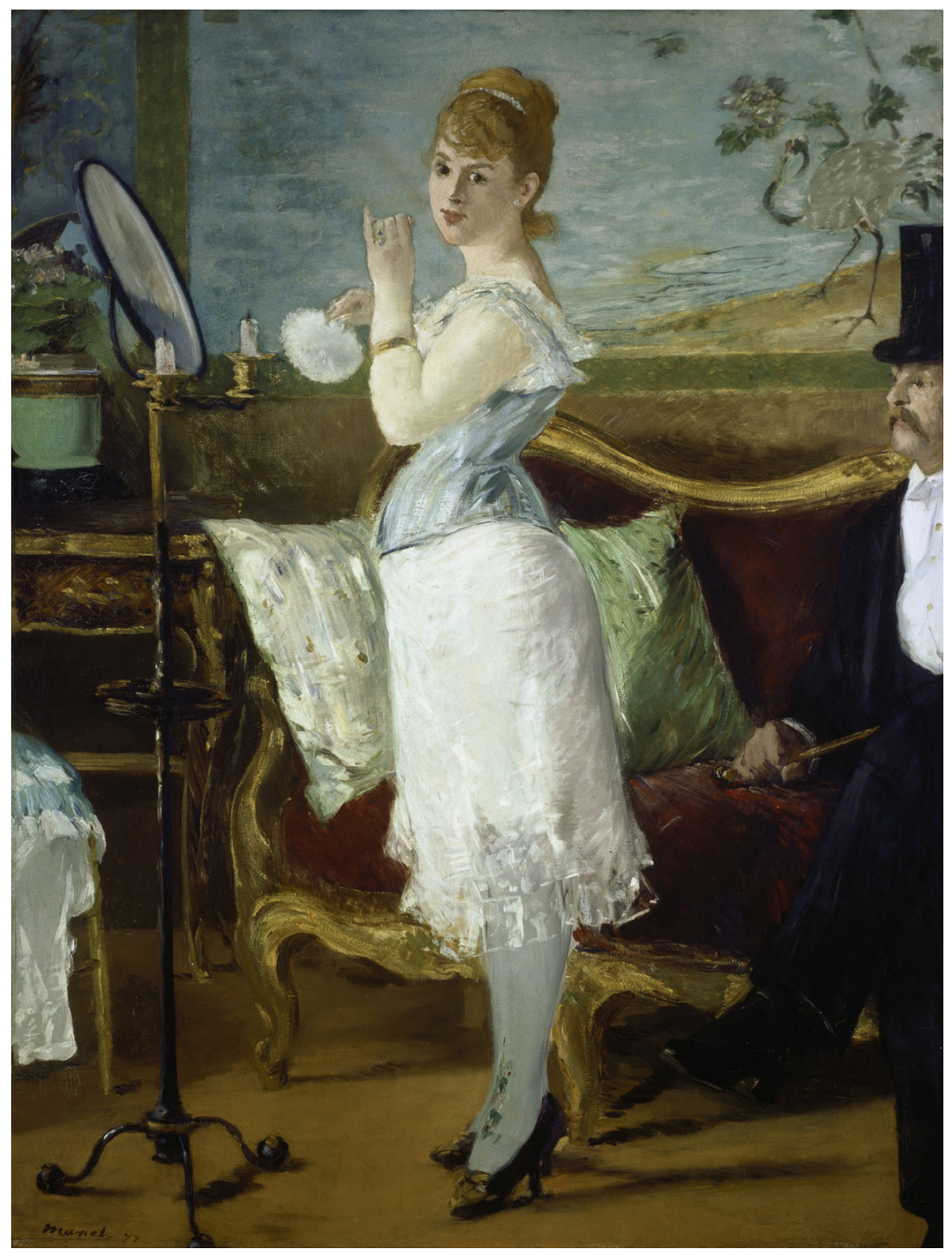

Photo I: Édouard Manet, Nana (1877), exhibited today at Kunsthalle Hamburg (Germany) 
man with all the impulsive madness of her sex, opening the gates of the unknown world of desire. ${ }^{6}$

This description of Nana as nude in act 2 is in sync with police records from Munich and reports from Vienna and Paris about the Belle Hélène bedroom scene in act 2. It is also in sync what Offenbach scholars such as Laurence Senelick who writes:

Offenbach sounds the leitmotif of sensuality. His opéras bouffes undermine the prevailing value system by exalting the sway of gaiety over earnestness, carnal love over sentiment. The heroines of Orphée aux enfers (1858), La belle Hélène (1864), La Grande Duchesse de Gérolstein (1867), and La Périchole (1868) exemplify this new hedonism: they are women who glory in their sexuality and are glorified for it. ${ }^{7}$

Obviously, there's a fine line between being glorified and being exploited. Senelick writes:

In provincial small-towns throughout Europe, young women who accepted contracts to appear in music-halls found that they were obliged to drink and sleep with the clientele, and their salaries were withheld to prevent their escape. This became known as la traite des chanteuses or white slavery of singers. ${ }^{8}$

It's important to remember here that operetta first came to the United Kingdom via music halls. In his 2007 book Emily Soldene: In Search of a Singer Kurt Gänzl writes: "[H]ere, in the music halls, [...] Offenbach had found precisely the kind of performer that his music demands."

What these drink-and-sleep-with-the-clientele venues offered - in Paris, in Vienna, Berlin, and London - were originally elitist spaces that reflect the liberal and anti-bourgeois attitudes of their audience. In his book Jacques Offenbach and the Paris of His Time (1937) Siegfried Kracauer observes:

The circle of fashionable gentlemen who were attached to grand courtesans included nearly 100 men, all of them from aristocrat-

6 Zola, Nana, 44-5.

7 Senelick, "Sexuality and Gender," 82.

8 Ibid., 92.

9 Kurt Gänzl, Emily Soldene: In Search of a Singer, vol. 1 (Wellington: Steele Roberts Ltd., 2007), 198. 
ic background and all of them characterized by a definitive authority in all questions of mundane behavior. Their frivolity expressed itself in their supreme contempt for the bourgeoisie: through an existence that consciously transgressed middle-class conventions and excluded serious work..$^{\circ}$

\section{Playground of the Happy Few}

First among these men who were Offenbach's original audience was Charles Auguste Louis Joseph, Count de Morny. Not only was he the openly acknowledged illegitimate half-brother of Emperor Napoléon III, he was also the head of the Corps Legislatif and as such one of the most powerful men in France. He possessed an "unquenchable nocturnal passion for the filles du ballet, the theater, and the music hall," we read in Alan Strauss-Schom's 2018 The Shadow Emperor: A Biography of Napoléon III. ${ }^{11}$ We also read there that Morny had a "sense of superiority over all men in all matters." ${ }^{\prime 2}$ His friend and fellow Jockey Club member Edmond D’Alton Shée states:

He made absolutely no attempt to conceal from the world that he had no political principles or that he held little faith in his fellow man. Nor did he ever let anything interfere with his personal freedom. ${ }^{\text {I3 }}$

It is rather unique in the history of music that such a man as the Count de Morny was godfather to Offenbach's only son, and also a close collaborator on various Offenbach shows; this includes writing the libretto for the social satire M. Choufleuri restera chez lui le... (Mr. Cauliflower will be at home on ...) in 1861.

Morny's senior secretary was Ludovic Halévy who had daily meetings and breakfast with his boss at the presidential residence in Hôtel de Lassay.

10 "Die Clique der mit den großen Kurtisanen liierten Lebemänner umfaßte annähernd hundert fashionable Herren, die fast durchweg der Aristokratie entstammten und eine unbedingte Autorität in allen Fragen des mondänen Verhaltens besaßen. Ihre Frivolität äußerte sich darin, daß sie die Verachtung, die sie für die Bourgeoisie empfanden, durch ein Dasein bekundeten, das sich absichtlich über die bürgerlichen Konventionen hinwegsetzte und ernste Arbeit ausschloß." - Siegfried Kracauer, Jacques Offenbach und das Paris seiner Zeit (Frankfurt a.M.: Suhrkamp, 1994 [1. edition Amsterdam, 1937]), 220-1.

11 Alan Strauss-Schom, The Shadow Emperor: A Biography of Napoléon III (New York: St. Martin's Press, 2018), 19.

12 Ibid., 20.

13 Edmond D'Alton Shée quoted in Strauss-Schom, The Shadow Emperor, 19. 
It seems obvious that the type of humor reflected in Offenbach's shows was Morny's type of humor, it's also very much the type of humor of the Jockey Club, and it's probably also the humor of Napoléon III himself who regularly attended Offenbach performances - even though he detested opera. Only with this kind of triple protection is it understandable that Offenbach's opéras bouffes were ever allowed to be performed in Paris in an otherwise highly restricted and censored theater system. "You know better than anyone," Offenbach wrote to Ernest Lépine, private secretary to Morny, "all that he has done for me ... how he went out of his way to protect us."'

That Morny surrounded himself with talented Jews - Halévy, Meilhac, and Offenbach - "did not go unnoticed by a disapproving aristocracy," writes Strauss-Schom. ${ }^{\text {is }}$ That Morny's mistress, Cora Pearl, later taken over by Napoléon III himself, went onto the stage in 1867 at the Théâtre des Bouffes $\mathrm{Pa}$ risiens for a revival of Orphée aux enfers as a demi-nude Cupid didn't go unnoticed either. There are lengthy articles in the press, British newspapers included, that report on the event and list the names of those who attended the opening night. It's a Who's Who? of the highest social circles in Europe, plus the entire (!) Paris based press. The Daily News from London writes:

The attraction was the see by strong gaslight and the aid of opera-glasses [...] the real form and features of a personage whom the non-privileged public had only been wont to admire in the manifold amplifications of skirts and crinoline. This attraction [...] raised the prices of the most uncomfortable single seats to two $\mathrm{Na}$ poleons [...]. A frisson d'attente, we are told, awaited the appearance of the débutante, who came forward with her stays and slippers - almost her only clothing - glittering with diamonds. ${ }^{16}$

Having catapulted Offenbach and opéra bouffe into the upper social spheres of France, and bringing representatives from other countries to opéra bouffe, meant that the genre quickly established itself in equal social regions elsewhere. About the situation in Vienna we read in Marion Lindhardt's Residenzstadt und Metropole: Zu einer kulturellen Topographie des Wiener Unterhaltungstheaters (1858-1918): "The interest of high and highest circles of the imperial family in productions of Offenbach in the

14 Offenbach quoted in Strauss-Schom, The Shadow Emperor, 20.

15 Strauss-Schom, The Shadow Emperor, 20.

16 Anon., "France," The Daily News [London], January 30, 1867. 
1860 s at Carltheater and Theater am Franz-Josefs-Kai is remarkable," writes Linhardt, "these shows were presented in a glittering setting."

Given the imperial stamp of approval it's not surprising that the Carltheater in Prateralle quickly became the "favorite playground of the moneyed classes and those who thrived to join in their ranks." Next to the imperial family, the entire

financial world, the wealthy middle classes, multitudes of stock brokers who enjoyed their moment in the sunshine of the economic boom, and the opulent flowers of the demi-monde, all came to parade in the luxury of vanity fair of (Prater) street,

writes the Illustrirte [sic] Zeitung. ${ }^{19}$

\section{Sexual Liberation on Stage}

What does such a performance situation mean for the actual shows? It's clear that the high class gentlemen and their mistresses did not primarily support operetta because of the melodic beauty and harmonic inventiveness of the scores. There must have been another dimension that attracted them, and that needs to be considered when dealing with Offenbach and/or opéra bouffe. That dimension was not just the brothel atmosphere of operetta theaters, but also the positive space that such an atmosphere opened up.

The sexual liberty demonstrated in operettas of this era is staggering; it's a counter concept to the prevailing moral value system of the time, which in France and Austria was dictated by the Catholic church. Offenbach's shows are decidedly blasphemous, poking fun at religious leaders again and again, but also at devout Christians like Bluebeard who believes he can only 'bed' a women if he marries her first, and who cannot divorce her afterwards, so he has to wait till death parts them. The grotesque consequences of such a mind-set are played out in the 1867 Barbe-bleue which starred Hortense Schneider as the lusty maid who brings the patriarchy crashing down and starts a revolution of women against male oppression and Catholic morals. She's a clear forerunner of women's suffrage, and a symbol for operetta's radical modernity.

17 Marion Lindhardt, Residenzstadt und Metropole: Zu einer kulturellen Topographie des Wiener Unterhaltungstheaters (1858-1918) (Tübingen: Max Niemeyer Verlag, 2006), 58.

18 Ibid., 34-5.

19 Anon., “Wiener Bilder. Der Prater," Illustrirte Zeitung (Vienna), May 21, 1881. 


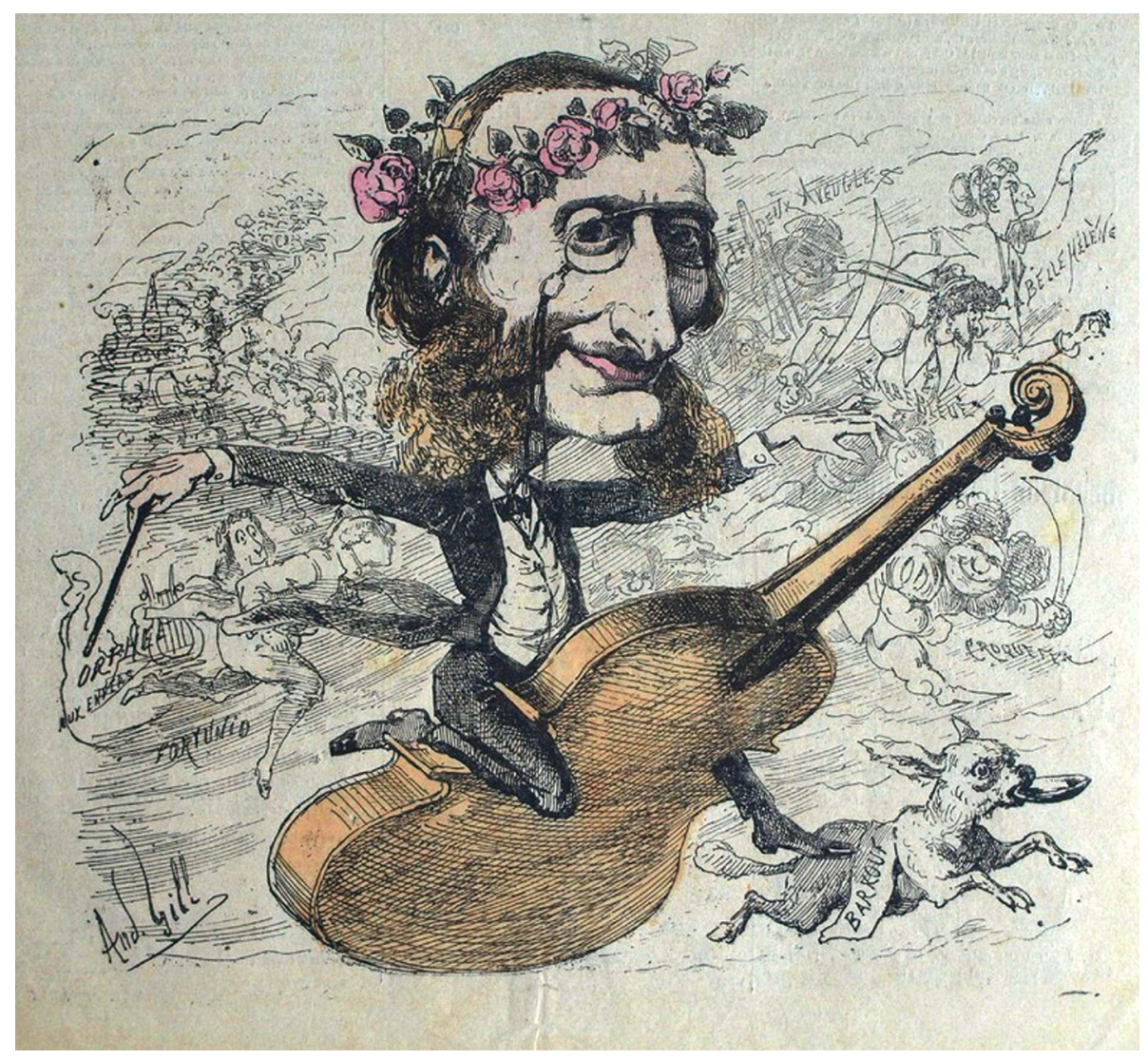

Photo 2: Caricature of Jacques Offenbach riding his cello and success, by André Gill (1866)

In the context of the liberated sexual politics inherent to operetta it was also possible for Offenbach and his librettist to present, in 1868, the first ever same-sex marriage story on the musical stage in L'île de Tulipatan. Just for the record: it is the same year in which Karl Maria Kertbeny first used the word 'homosexuality' as an antonym for 'heterosexuality' and 'monosexuality.' And it is only one year after Karl Heinrich Ulrichs had the world's first public coming-out in 1867 at the German lawyer's conference in Munich, in front of 500 colleagues. He wanted to present the idea of legally accepting marriage for 'Urninge,' i.e. gay people. He did not get to that point because he was booed off the stage. Still, that day marks the beginning of the modern gay rights movement. And the writers of operetta picked this up immediately. 
They also celebrated another hot topic: gender nonconformity. If Hortense Schneider as Boulotte in Barbe-bleue led the feminist revolution against the patriarchy, operetta also celebrated cross-dressing and allowed female performers to slip into a 'macho' role denied to them by society at large. It also allowed men to cross dress (e.g. in Offenbach's Mesdames de la Halle, 1858) and explore a transgender and possibly homosexual side of their personality in public that was criminalized elsewhere and only just about tolerated in France.

The ever-present cross dressing links early operetta closely to burlesque. While burlesque, in those years, was different to operetta because it recycled existing music, whereas operetta offered new scores, the style of performance and topics chosen were similar. In his essay "The New Taste in Theatricals" William Dean Howell writes about burlesque and Lydia Thompson visiting the United States with her British Blondes in the late 186os:

Though they were not like men, they were in most things as unlike women, and seemed creatures of a kind of alien sex, parodying both. It was certainly a shocking thing to look at them with their horrible prettiness. ${ }^{20}$

Burlesque has rarely been examined by operetta historians as a related art form. Even though what William Dean Howell writes about burlesque in the USA in 1869 is similar to what many others have written about operetta in Vienna and Berlin, London and Paris at the exact same time. The points Robert C. Allen makes in his book Burlesque and American Culture in 1991 about gender ambiguity apply to operetta as well, and considering that today we are discussing the question 'What does it mean to be a Woman?', or 'a Man' for that matter, more intensely than ever before in the wake of the unfolding trans movement, it's astonishing that operettas have been completely excluded from these debates. And that applies also to research into operetta's role in LGBTIQ history.

The remarkable sexual liberty associated with operetta explains why the new genre spread around the world like a wild fire, also to England. One famous venue for Offenbach performances was the Alhambra, where Belle Hélène was first presented in London. Kurt Gänzl writes:

The audience at the Alhambra was, like its stage, its auditorium and its corps de ballet, a large one, with varying purposes in their 
visits. And not all of these purposes were to do with music. [...] [T] he ballet-girls, of course, were considered prime prey by the more libidinous young and not so young men-of-the-town. But if you couldn't catch a ballet-girl [...] and your libido had been sufficiently stoked up by watching them perform, the Alhambra also had the most notorious promenade in town, a walkway [...] at the back of the auditorium stocked with the usual array of prostitutes for all seasons. ${ }^{21}$

London got to see the most notorious of all Belle Hélènes in the flesh: Hortense Schneider. She came to England and presented her Grand Duchess at the St. James's Theatre, French impresario Raphaël Félix paid her the unheard-of amount of $£ 80$ a night. After a tour of the provinces, Miss Schneider returned to London and played the Grand Duchess at the Princess's Theatre. The Era reports:

Crowded stalls and the rest of the house all but empty, speak better than any word of ours the relative opinions of the upper and middle classes on the subject of decency. It is quite clear that the middle classes are jealous of hurting the modesty of their wives and daughters, and it seems equally certain that in the aristocratic circles these delicate little attentions are not so much considered. [...] Accordingly, the 'can-can' is an extravagant riot, and very few in the cast do not follow the wild and reckless lead of the pretty lady with the slashing whip. [...] Lightness, sparkle, recklessness, high spirits, all these things we get in abundance. There is only one thing wanting and that is - respect for the audience. But perhaps the audience does not care to be respected. Who knows? ? $^{2}$

Such 'riotous' performances in England were not restricted to Offenbach; Hervé shows proved equally popular. They also demonstrate the importance of male stars that lured female audiences who in turn lured male theater goers in. We read about this in Emily Soldene's autobiography in which she describes the production of Hervés Chilperic in London which had a certain C. D. Marius as the "little shepherd" Landry:

Young and beautiful, and slender, and sleek, and sly and so elegant. [...] He played Landry, and made love to Frédégonde or Brunehaut,

21 Gänzl, Emily Soldene, 250.

22 The Era quoted in Gänzl, Emily Soldene, 354. 


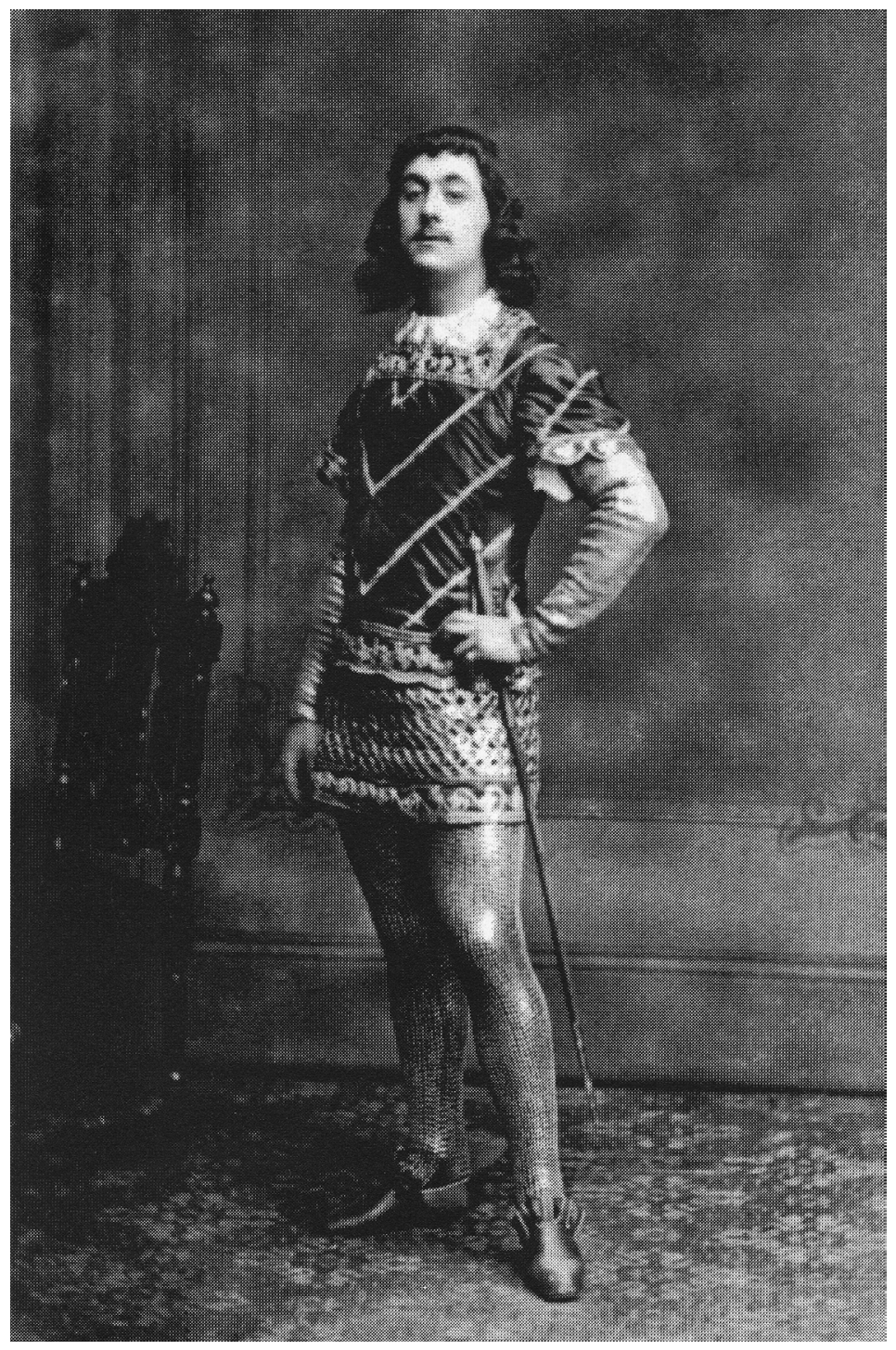

Photo 3: C. D. Marius (Claude Marius Duplany) as Landry in Hervé's Chilpèric, London I868

he didn't care which, with an ardour that was not only particularly French, but particularly pleasing and particularly successful, so successful indeed that every girl in the front of the house was seized 
with a wild desire to understudy those two [...] imprudent characters. He certainly looked awfully nice, his figure being perfection. ${ }^{23}$

It's a dimension to operetta performances - and their success back in the 1860 o and 70 - that has not been examined by historians either. In the context of today's casting politics, let's say by Netflix, to attract female teenage viewers, a discussion of male stars in operetta and the effect they had on the reception of the shows seems overdue. Because isn't Mr. Marius a clear forerunner of heart throbs such as Jacob Elordi and Noah Centineo?

First and foremost, though, it was the leading ladies who sold the shows and made operetta a phenomenon, also in the United States. New York discovered the joys of opéra bouffe in 1867 when Hezekiah Linthicum Bateman imported a French company, with Lucille Tostée from the Paris Théâtre des Bouffes Parisiens as its prima donna, playing La Grande-Duchesse. This was followed in 1868 by a production of Genevieve de Brabant. The Tribune reported on 22 October 1868 :

Mr. Grau has distinguished himself by producing at the French Theatre the most revolting mass of filth that has ever been shown on the boards of a respectable place of amusement in this city. [...] Geneviève is not merely indecent, but it grovels in a low depth, even below decency. ${ }^{24}$

\section{Operetta as Family Entertainment}

With such moral outrage gaining momentum, not just in New York, it was only a matter of time till the pendulum swung back. This happened after the French-Prussian war was lost by the French in 1870/71. Suddenly, all things associated with the Second Empire were spurned. (This is the situation in which Zola writes Nana.) At the same time, interest in the genre operetta spread and reached the middle classes who wanted their share of the fun. Laurence Senelick writes: "Bourgeois society, more venturesome in its money-making and more secure in its income, aspires to imitate the court."'s

What happens when the spurred-and-ridiculed-for-their-morals suddenly enter the safe space of aristocratic operetta and fill the stalls that had been left empty when La Snédèr performed in Gerolstein? A counter movement can be discerned in Austria in the 188 os with a new wave of shows

Emily Soldene quoted in Gänzl, Emily Soldene, 320.

24 Quoted in Gänzl, Emily Soldene, 416.

25 Senelick, "Sexuality and Gender," 82. 
by Millöcker, Ziehrer, Zeller, striving for 'respectability' and a more 'Singspiel' format. It's a counter movement that can also be witnessed in England, with Gilbert \& Sullivan at the forefront.

This means that another form of safe space was created, a space where it was possible to take the family without having to fear for their reputation. Carolyn Williams in her 2011 book Gilbert and Sullivan: Gender, Genre, Parody calls it "a capitulation to bourgeois respectability" ${ }^{36}$ because the authors and producer made a decision "to emphasize the respectably of the $\mathrm{Sa}$ voy operas." Williams calls this "a canny attempt at niche marketing."

Gilbert especially was scrupulous - even avuncular and fussy about correct middle-class feminine behavior, insisting that the female members of the Chorus not be thought coarse in any way. [...] The women of the Savoy Chorus were marketed as exceptionally beautiful, but chaste - to be looked at, but not to be approached. ${ }^{28}$

So, after the initial boom of operettas à la Offenbach and Hervé, we get a second boom that wanted to create an almost opposite safe space for respectability-focused audiences who wanted to enjoy the thrill of operetta, without having to fear for their good name. Which doesn't mean that in Gilbert \& Sullivan, or Zeller, Ziehrer and Millöcker, there isn't an undercurrent of original operetta naughtiness.

In his novel Operettenkönige: Ein Wiener Theaterroman, Franz von Hohenegg describes the situation at Theater an der Wien and the 1905 premiere of what is, in effect, Mizzi Günther singing the Merry Widow, here as 'Mizzi Rittmann' performing with tenor 'Arno Springer' (= Louis Treumann, famous for his acrobatic jumping). We have moved forward three decades from the original Offenbach and operetta boom, also in Vienna. Still, the operetta diva in Hohenegg's novel has had sex with almost everyone in the stalls. About her opening night at the Theater an der Wien we learn:

The hautvolee and the hautdemimonde are certainly and completely present. [...] The balconies are filled with state employees

26 Carolyn Williams, Gilbert and Sullivan: Gender, Genre, Parody (New York: Columbia University Press, 2011), 20.

27 Ibid.

28 Ibid., 21. 
who could never afford the luxury of such a visit for their wives and daughters if someone had not given them free tickets. ${ }^{29}$

What Hohenegg describes is an interesting blend of spheres that is and remained - typical of the operetta business. Operetta had become a balancing act, trying to find the right mix of extremes to satisfy opposing audience expectations. The elitist audience had moved mostly underground in the 1880 s and 9os, as Marion Linhardt describes in Residenzstadt und Metropole. She remarks that high-class operetta audiences went to more secluded cabaret venues where the genre blossomed as late-night entertainment, often composed by the same authors who wrote the large scale works for the masses. These cabaret operettas incorporated the latest trends, dance crazes and structural elements. Syncopations and the cake walk, for example, all came to Continental Europe from the United States and England via these elitist miniature operettas, and only then infiltrated the mainstream genre.

Depending on where operettas were performed - and who attended them -, the genre was shown in different guises. Often, the intimate venues were situated in the same theaters where the big operettas were performed, and select audiences who could afford to do so would go from the large auditorium to the 'safe space' of a night club for one-act operettas such as Der Petroliumkönig oder Donauzauber: Musteroperette in zwei Bildern by Egon Friedell and Sch. Konrad (1908) or Elektra by Béla Laszky (1910) which starred Mela Mars. In Vienna, there was Die Hölle in the basement of the Theater an der Wien, in Munich there was Die 11 Scharfrichter, in Berlin there were many venues, among them Kabarett der Komiker or Die Wilde Bühne (in the basement of Theater des Westens). Actors and actresses also went from the main evening performance to the cabaret and continued performing throughout the night, in the 1920 s they added film engagements during the day to this type of job hopping; Max Hansen, the original Leopold in Im weißen Rössl, is a famous example. Which brings us back to Heike Quissek and her assessment that anything can be played as operetta, and that operetta can be played as everything else, too.

29 "Die Hautevolee und die Hautedemimonde sind sicherlich vollständig vertreten. [...] Die oberen Ränge sind fast ausnahmslos mit Beamten angefüllt, die sich, ihren Frauen und Töchtern den Luxus eines Premierenbesuches wahrlich nicht leisten könnten, wenn ihnen eben nicht unter der Hand die Karten zugesteckt worden wären." - Franz von Hohenegg, Operettenkönige: Ein Wiener Theaterroman (Berlin: Hermann Laue Verlag, s. a.), 181-2. 


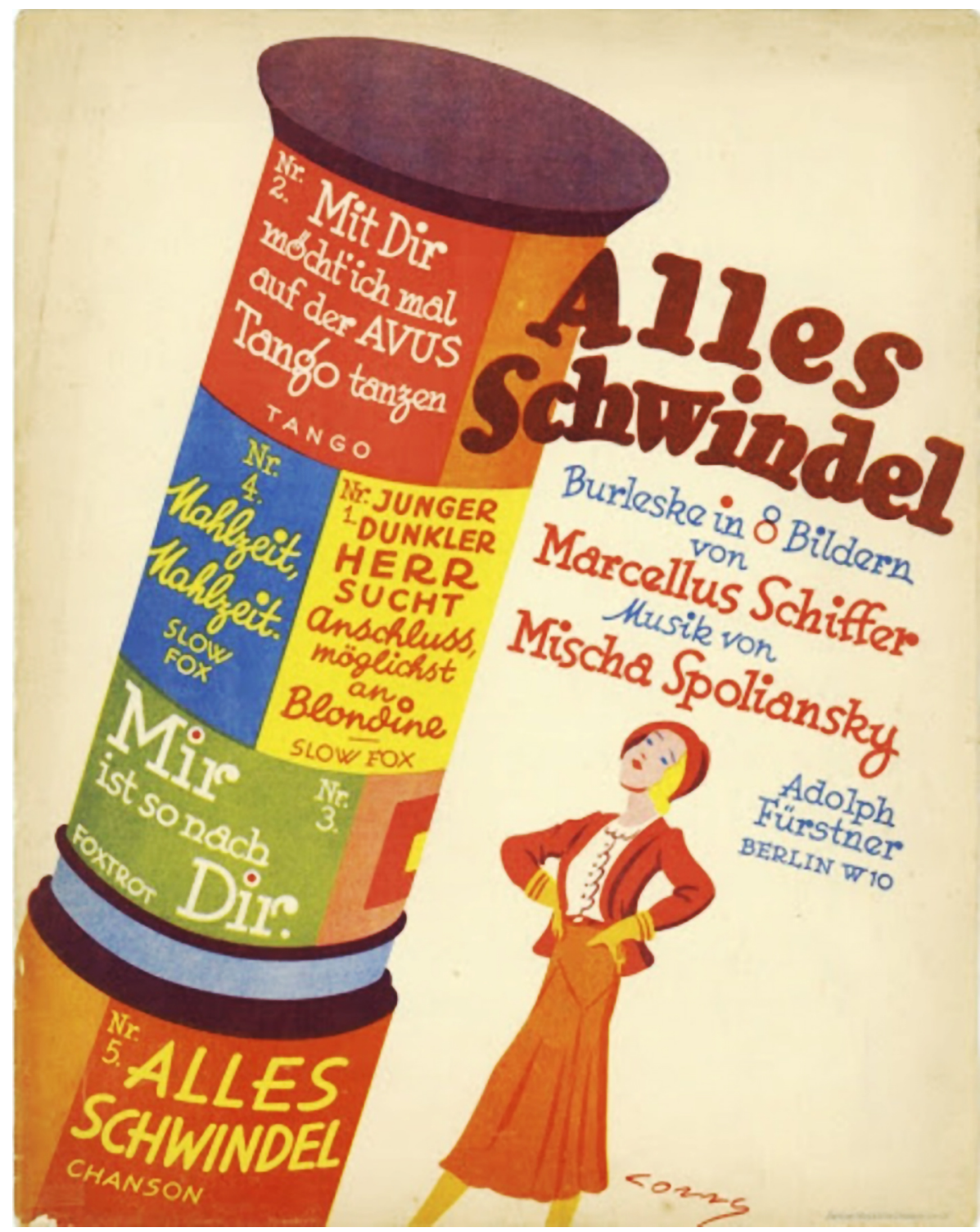

Photo 4: The original poster for Alles Schindel, Berlin 1931

The Triumph of Nostalgia

In the 1920 s and early 1930 operetta continued thriving as a commercial genre that moved successfully between different audience-demands and incorporating different popular elements as they came along. All shows up 
until 1933 can be seen somewhere on the spectrum of radical elitist 'original' operetta and 'cleaned-up' operetta-for-the-masses. This brought forth a surprising multitude of shows that catered to all tastes and trends: be it a love for the old-fashioned in Försterchristl, Dreimäderlhaus or Schwarzwaldmädel, or syncopated Charleston pieces such as Die Herzogin von Chicago, not to mention Abraham's whirl-wind Blume von Hawaii and Ball im Savoy. There were also small-scale satires, such as Alles Schwindel or Rufen Sie Herrn Plim by Mischa Spoliansky, there were the revivals of Johann Strauss (arranged by Erich Wolfgang Korngold), there were the out-and-out operatic pieces by Franz Lehár written for Richard Tauber, and there were film operettas with scores by Werner Richard Heymann, also ranging from nostalgia (Der Kongress tanzt) to contemporary (Die Drei von der Tankstelle).

In 1933, this system came to a complete halt when the Nazis took over power and introduced a new state-subsidy system in Germany that gave them control over the entire theater and entertainment world, just like it gave them control over almost everything else. From then on, all programs had to be approved by the Reichsdramaturg, so instead of following popular trends, operetta now followed orders from above.

The Nazis basically erased the elitist and avant-garde version of operetta and celebrated the ideal of a 'Golden Operetta' with Johann Strauss and his waltz scores as the highest possible form the genre can strive for. Politics (and political jokes) were taken out of operetta by direct order from Goebbels. Instead, audiences got indirect indoctrination which Goebbels deemed more effective. Lascivious sex was labeled 'degenerate' and 'sick,' a form of 'Jewish smut,' just like jazz, and both were turned into a new Aryan version of 'modern rhythms' and a new form a 'heroic' nudity to satisfy the tastes of audiences who had grown used to the more modern versions of operetta, and did not appreciate old fashioned titles like Die Fledermaus and Der Zigeunerbaron as an exclusive diet. Nevertheless, Goebbels and his propaganda ministry tried everything to make precisely these titles appear attractive to the masses: apart from superstar opera versions, Goebbels stimulated equally star studded film version of 'Golden Era' operettas such as Vogelhändler, Bettelstudent, Gasparone, Wiener Blut, Frau Luna, Fledermaus and so forth.

Were operettas a safe space in Nazi times? In many ways: yes. As I just said, you could be fairly sure that an operetta film or stage performance was free of direct propaganda, as operettas were intended to 'relax' weary 


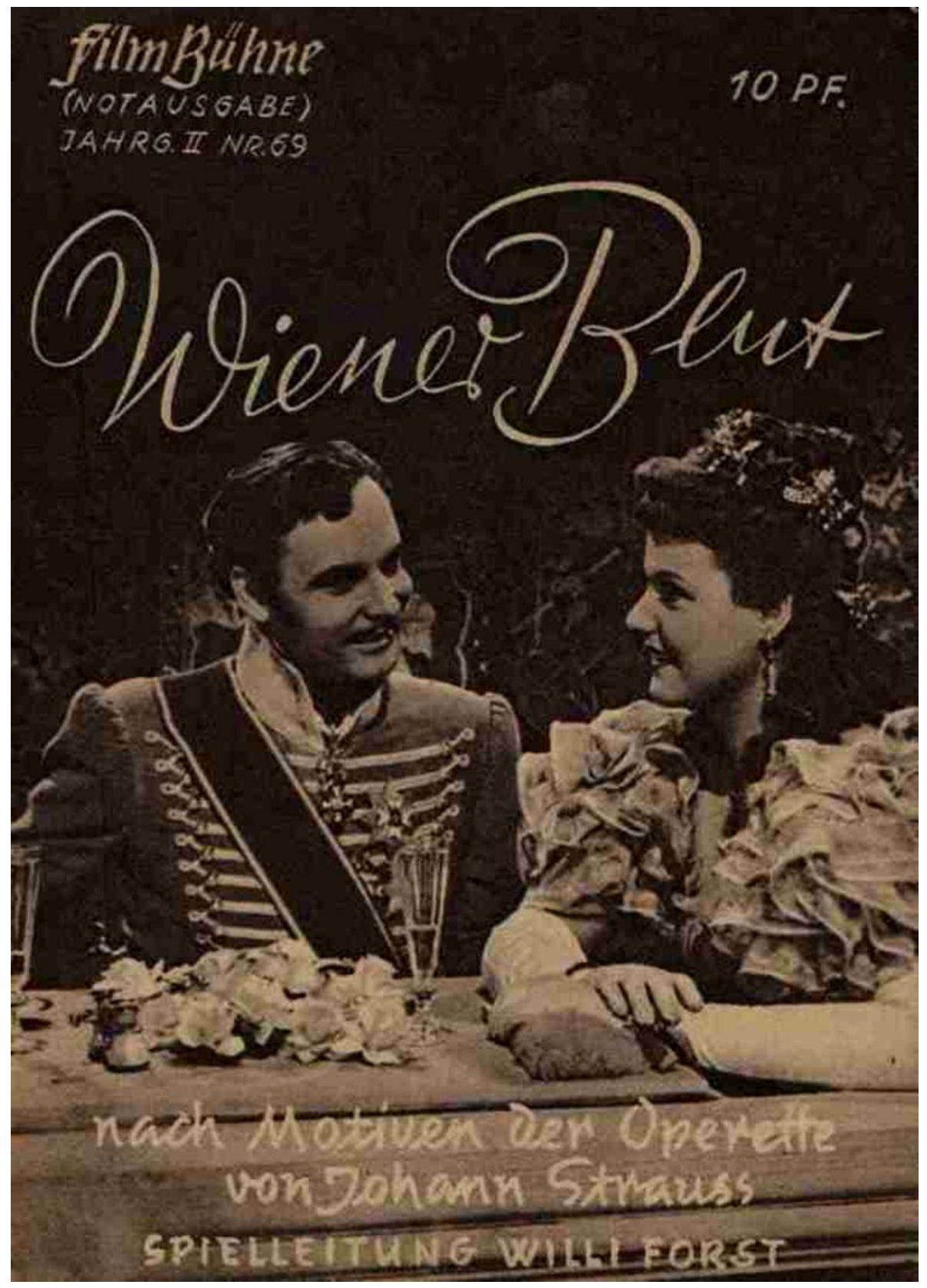

Photo 5: An edition of Film-Bühne with the Willi Forst version of Wiener Blut on the cover, 1942 
audiences tired from work and war, and tired of a constant confrontation with Nazi symbolism. Goebbels wanted to reach them in a different way; and he did. Audiences could also be sure that any sexual double entendre in operetta would not lead to embarrassing situations; either for the characters on stage or for the people in the auditorium. The new ideal was operetta as 'Singspiel': with a 'true' German humor that could be found in the comic operas of Albert Lortzing. In the 1939 Reclams Operettenführer Hans Severus Ziegler recommends Lortzing's Der Wildschütz as a role model to strive for.

Meanwhile, in the US and UK, operetta had also become associated with being 'old fashioned,' a nostalgic alternative to the up-to-date musical comedies of Gershwin, Jerome Kern, Cole Porter, Rodgers \& Hart, and later Rodgers \& Hammerstein. That doesn't mean they were unsuccessful: Romberg's The Student Prince was a massive hit on Broadway in the 1920s, Ivor Novello's and Noel Coward's operettas were comparable hits in the West End. But they now catered to a different audience.

\section{A Most Ingenious Paradox: 1933 vs. 1945}

With regard to Germany, it wasn't until after 1945 that the full consequences of the Nazi re-definition of operetta really hit, even though it is a common belief that the radical changes befell the operetta industry in 1933. But that is only partly true. Dagmar Herzog has written many books about sexuality under German Fascism. In a small publication entitled Paradoxien der sexuellen Liberalisierung she summed up her theory in 2013: "The whole era of the Weimar Republic was reduced to sexuality. [...] The image of Germany as a hothouse of decadence and promiscuity between 1919 and 1933 was cultivated. ${ }^{30}$ The churches praised the new regime's sexual politics in 1933, saying "with one swipe everything changed in Germany, all the dirt and filth (Schmutz und Schund) disappeared from the public eye."3r But after only two years Christian leaders were disappointed.

The specific innovation of Nazi sexual politics was the attempt to combine the growing societal interest in sexual happiness with a deeply anti-Semitic and in a wider sense racist - anti Roma and Sinti, anti Slawic, anti handicap - and soon also massively homo-

30 Dagmar Herzog, Paradoxien der sexuellen Liberalisierung [Hirschfeld-Lectures series] (Göttingen: Wallstein Verlag, 2013), 24. 

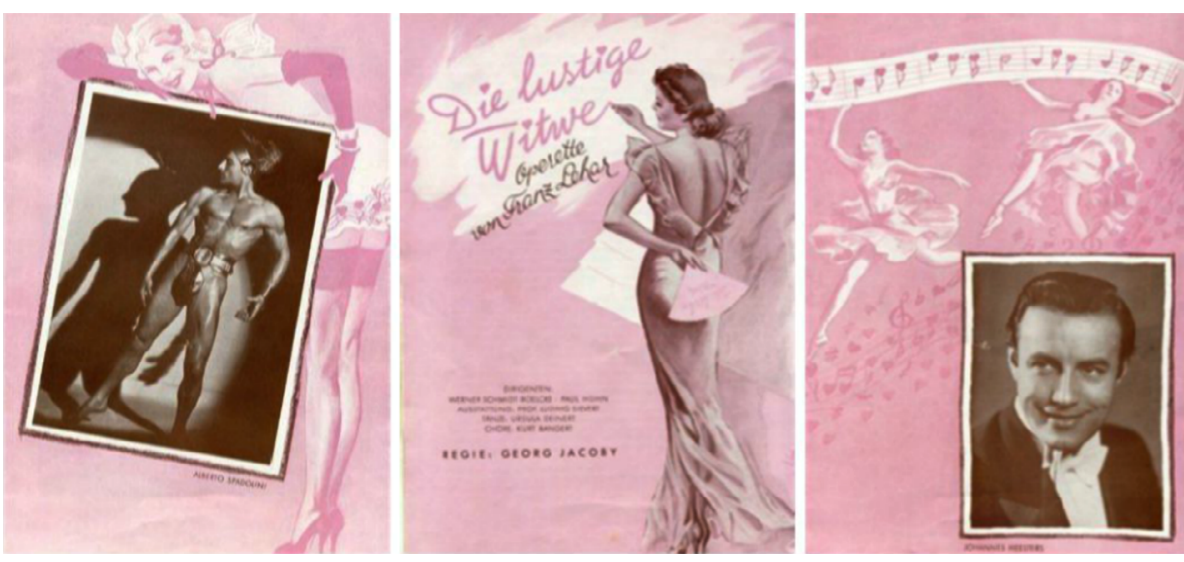

Photo 6: The program for Die lustige Witwe production by Georg Jacoby with Johannes Heesters (r.) and nude dancer Alberto Spadolini (1.), Berlin 1940 (Collection Marco Travaglini/Atelier Alberto Spadolini)

phobic program. Via a combination of incitement and denial, attacks against 'Jewish' morals combined with recommendations for free actions, the 'Master Race' was encouraged to enjoy its privilege. Within a few years it became clear that the new regime blatantly advocated pre-marital coitus between teenagers and from the early 1940 on onwards they openly endorsed adultery. This was not just about higher reproduction rates, but also about higher lust and in the end the idea that this happiness given to the people was a gift from the brown rulers. ${ }^{32}$

Herzog's conclusion is this:

As paradox as it may sound, the Nazis managed to fuse the wide spread longing for sexual happiness with the racial and ideological privilege of the approved non-handicapped heterosexuals, i.e. the majority of the population. ${ }^{33}$

This affected operetta, too. Interestingly, the operetta productions that reflect this pro-sex and pro-nudity ideal of the Nazis have been almost completely erased from memory. One is a Lustige Witwe production from Berlin 1940, directed by Georg Jacoby. It had Alberto Spadolini as a nude male dancer from Italy. Spadolini had appeared together with Josephine Baker at

32 Herzog, Paradoxien der sexuellen Liberalisierung, 28.

33 Ibid., 29. 


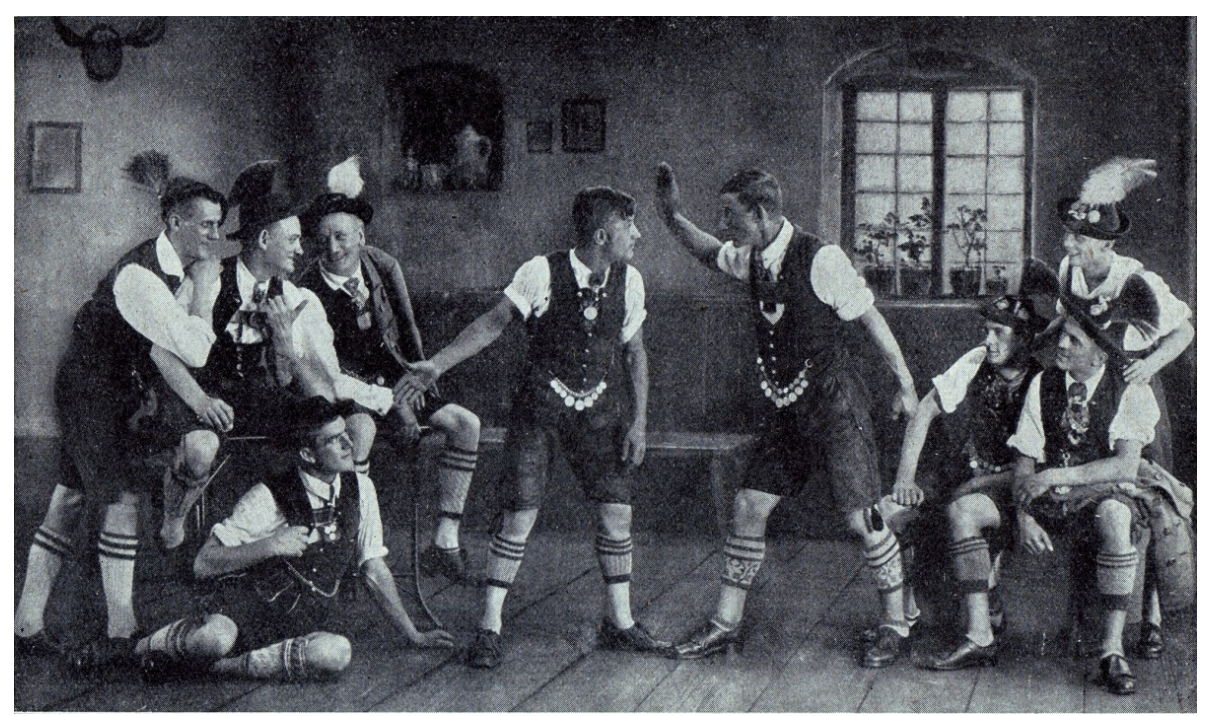

Photo 7: The "Tiroler Gruppe" as originally used by Erik Charell in the revue Für Dich, Berlin 1925. Erich Urban wrote about them in BZ am Mittag: "Saftige Kerle in Lederhosen, die sich im Takt Dinger herunterhauen. Mein Gott, sie haben die kernigen Backen dazu!" "Juicy lads in leather pants who slap each other rhythmically. My god, they have the right butch bums/ cheeks for it.")

the Casino de Paris in the 1920s, he was rumoured to be a foreign (anti-Nazi) spy, and he had same-sex affairs. Did operetta offer him a safe space in the heart of Nazi power, in performances attended by the 'Führer' and his top officials? And what was his open display of muscle and flesh about? Did the Nazis want to offer women whose boyfriends and husbands had been sent to the front lines of war a chance to marvel at heroic male forms - as an update of attractions such as C. D. Marius?

The difference is that inserting Spadolini into a Lehár operetta has strong ideological messages: catering to female lust, as in Chilperic, is one thing, doing so in the context of a world war another, emphasizing the axis Berlin-Rome and the partnership with Mussolini and celebrating the ideal of the Übermensch is a far cry from the emancipated approach to operetta from London in the 1870 os. But Spadolini can be seen in that tradition, which is what Matthias Kauffmann does in his book Operette im 'Dritten Reich': Musikalisches Unterhaltungstheater zwischen 1933 und 1945. He also sees Spadolini in the tradition of the Weimar Republic revue operettas, including the homoerotic elements that can be found in Erik Charell productions such as Im weißen Rössl (1930). The Jewish 'defilement' of Alpine 
culture that the Nazis accused Charell of is substituted here by the 'safe' ideological heroism of Spadolini; the entire Rössl itself was re-rewritten by Fred Raymond as Saison in Salzburg as a 'safe' Tyrolean yodel romp without any 'triggers' and with no problematic gender bending, no roll-in-thehay between Leopold and Piccolo. Raymond's operetta characters are as straight as they can be, and his Tyrolean dancers were to be admired, not to be taken home after the show like Charell's hand-picked 'Tiroler Gruppe.'

The interactive side of operetta was now restricted; the genre had become passive and dumbed down entertainment for the tired masses, not an active elitist playground with carnal and intellectual stimulation.

\section{Operetta and Existentialism: Erasing the Triggers}

All of this went on until 1945. But what happened then? What happened when the horrors of the Holocaust became known and Germans had to justify their prior carefree and often sexually liberated behaviour? The Christian churches in Western Germany claimed that in order to rebuild the country there was a need for 'cleanliness' and 'family values.' The result was a conservative sexual culture that stylized itself as a counter movement to the Third Reich. ${ }^{34}$ The newspaper Christ und Welt voiced its disgust in 1951 at the thought that sexual autonomy could be part of the new constitution's guarantee of 'free development of one's personality', because that would be in opposition to 'the divine commandments.'.5 Dagmar Herzog writes that

the cleaning-up after the mass murders was ultimately handled by shifting the German moral discourse to a narrow sexual-moral track; and again coping with the past (Vergangenheitsbewältigung) was achieved via sex. ${ }^{36}$

As a consequence there were harsh homophobic laws and an oppressive moral climate. How did operetta fit into this? It offered a safe space for traumatized citizens who wanted to escape the realities of life in ruins with shows such as Schwarzwaldmädel, Försterchristl, or Im weißen Rössl, and that did not want to be confronted in any way with double entendres reminding them of the rape of thousands of women by Russian soldiers as they had fled from Silesia or elsewhere.

34 Ibid., 35.

35 Quoted in Herzog, Paradoxien der sexuellen Liberalisierung, 36.

36 Ibid., 33. 


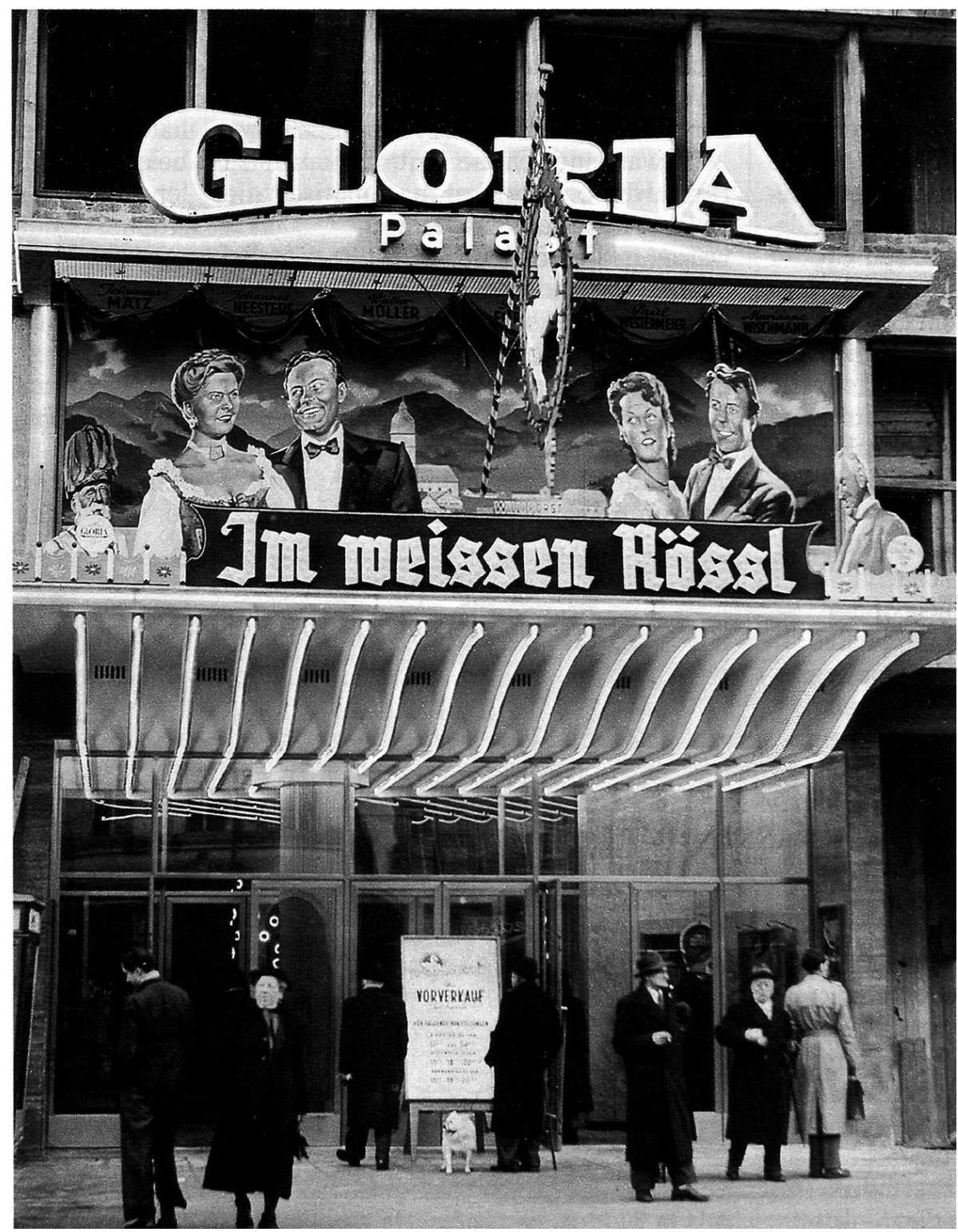

Photo 8: The entrance to a cinema in post-war West-Berlin playing the 1952 version of Im weißen Rössl with Johannes Heesters and Johanna Matz in the lead roles 
Operetta's main goal was to offer a nostalgic world were the horrors of war were invisible. A prime example for this is the phenomenal success of the 1950 film version of Jessel's Schwarzwaldmädel offering opulent apple blossom scenes, folkloristic costumes, and toned-down sexual humor that was never confrontational. The same is true for the many film operettas that followed this example, especially Im weißen Rössl (1952) or the saccharine Dreimäderlhaus (1958), both starring Johanna Matz as the other 'innocent' darling of German post-war audiences.

In the boom of post-WW2 operetta many once 'raunchy' titles from the Weimar years were resurrected, but they were now performed by opera singers on the radio and in subsidized theaters who treated the insinuations so 'operatically' that any textual meaning was neutralized and it was above all the carefree music that enraptured audiences. Austrian journalist Bertram K. Steiner wrote as late as 1997:

One arrives at operetta as a veteran of existentialism, after one has realized that progress and regression lead to the same inferno. For radicals and bigots of all coloring, for immoral optimists, operetta is a horror, of course. They will learn soon enough how idiotically soothing it is to be wedded by the little finch (Dompfaff) and afterwards do as the swallows do. ${ }^{37}$

Operetta, according to this definition, is a pain killer.

In a perverted way, the situation in the US was not so very different. There, too, society underwent a conservative roll-back after 1945. And this affected operetta audiences who turned to the genre now with the same longing for 'nostalgia' as in Germany, not to grovel in the lowest depths of indecency as in the times of Genevieve de Brabant. As Richard Traubner puts it in his 2003 updated edition of Operetta: A Theatrical History:

Operetta! Flowing champagne, ceaseless waltzing, risqué couplets, Graustarkian uniforms and glittering ballgowns, romancing and dancing! Gaiety and lightheartness, sentiment and schmaltz. ${ }^{38}$

37 Bertram Karl Steiner, "Operette und Existentialismus. Über ein schmerzstillendes Mittel," in Das Land des Glücks. Österreich und seine Operetten, eds. Erik Adam and Willi Rainer (Klagenfurt, Ljubljana, Wien: Hermagoras Verlag, 1997), 22.

38 Richard Traubner, Operetta: A Theatrical History (Abingdon-on-Thames: Routledge, 2003), vii. 
And what about the United Kingdom? Gilbert \& Sullivan had become an 'institution' there like Westminster Abbey as BBC journalist Leslie Baily phrases it in 1951:

Delightful, ridiculous, gay, melodious, satirical, ranging in style from the brilliant fire-works of Trial by Jury to the near-grand-opera of The Yeomen of the Guard, they are to the British a national possession - as Gilbert himself said, 'world-known, and as much an institution as Westminster Abbey. ${ }^{39}$

On the Gilbert \& Sullivan Online Platform, established in 1993, a discussion can be found about Oscar Wilde, Aestheticism and Effeminacy with regard to Patience. There, a certain Robert Jones writes:

I would agree with previous posts regarding [Gilbert]'s supposed nods in the direction of sexual innuendo. I think he would be mortified by the idea that his spotlessly clean libretti might conjure up lewd thoughts in his audiences' minds. ${ }^{40}$

As in Germany and the United States, UK operettas needed to be spotlessly clean as well.

As a result the "genre is almost extinct in the UK," Richard Bratby writes in The Spectator in 2018..$^{4}$ Neither the wild romps of Offenbach and Hervé have had a career in the UK after 1945, nor did the cheeky 2002 re-write of HMS Pinafore by American author Mark Savage, entitle Pinafore! and relocated to a gay cruise ship departing from Palm Springs, get much attention from traditional Savoyards. 2006's Gilbert \& Sullivan inspired The Beastly Bombing: A Terrible Tale of Terrorists Tamed By the Tangles of True Love (music: Roger Neill, lyrics: Julien Nitzberg) did not fare much better, notwithstanding a rave review of the original production in Los Angeles in The New York Times. It is too disturbing and political an operetta, and sexually outrageous, for modern day fans of the genre. As Silvia Bovenschen re-

39 Leslie Baily, The Gilbert \& Sullivan Book (London: Cassell \& Company Ltd., 1951), ix ff.

40 Robert Jones, comment in "Patience: Savoy Net Discussion. Oscar Wilde, Aestheticism and Effeminacy." on the website Gilbert and Sullivan Archive, https://gsarchive. net/patience/discussion/wilde.html.

41 Richard Bratby, "Operetta is serious business in Bad Ischl - and seriously glorious," The Spectator [spectatopr.co.uk], August 25, 2018, https://www.spectator.com. $\mathrm{au} / 2018 / 08 /$ operetta-is-serious-business-in-bad-ischl-and-seriously-glorious/. 


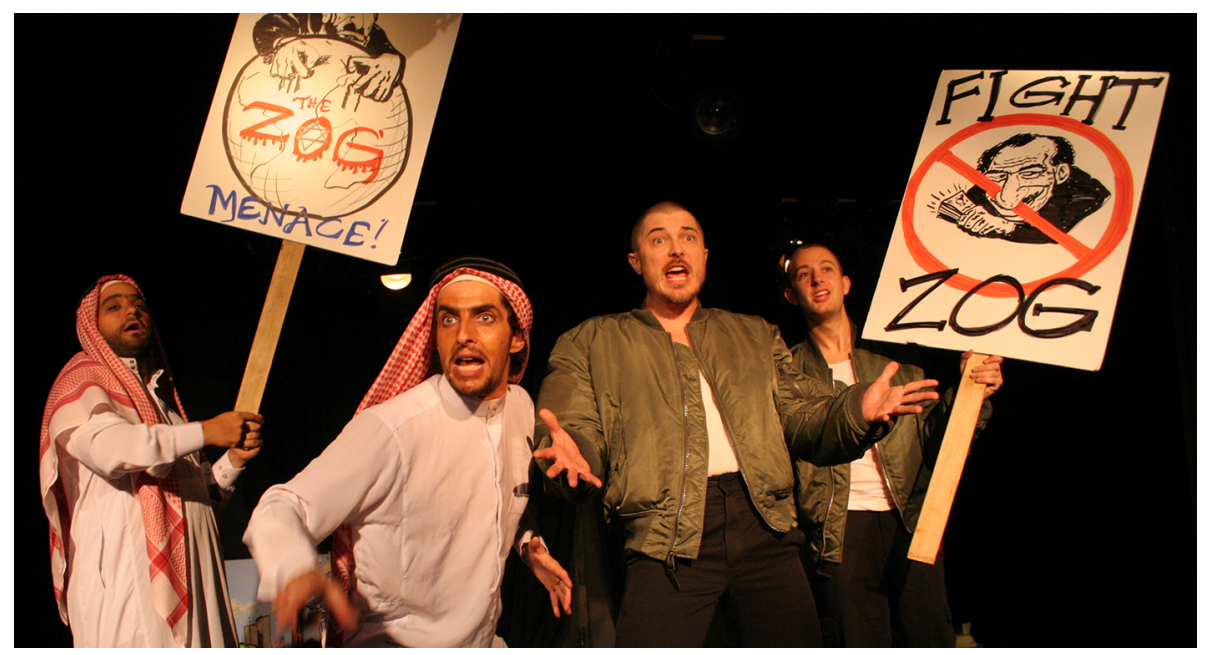

Photo 9: The terrorists in Julien Nitzberg and Roger Neill's "very model of a modern operetta" The Beastly Bombing: A Terrible Tale of Terrorists Tamed by the Tangles of True Love, Los Angeles 2006 (Photo: Kim Gottlieb Walker)

marked: in the course of continuing popularization almost every movement turns into its own caricature. ${ }^{42}$

We could apply Bovenschen's verdict to operetta: what we have seen as operetta in the past decades is a caricature of original opéra bouffe ideals and even of various once popular counter movements. What is presented as 'traditional' at venues such as Ohio Light Opera or the Lehár Festival in Bad Ischl, Volksoper Wien or the annual outdoor Mörbisch festival are versions of operetta to which Bovenschen's verdict applies. Combined with many lackluster performances by opera companies, and an endless series of horrendous TV broadcasts and films, and a constant re-issuing of problematic post-WW2 recordings that interpret operetta like a Lortzing 'Singspiel' have more or less killed the genre as a relevant art form of broader public appeal, leaving a small zombie-like group of followers who don't ever seem to die out and want their operetta exactly like this: a 'safe' neardeath experience.

\section{Back to the Future?}

Which brings us to the present-day: why should anyone in general, or academics in particular, take note of operetta? Why should audiences beyond 42 Silvia Bovenschen, Älter werden (Frankfurt a. M.: Fischer, 2013), 172. 
the zombie core group attend operetta performances? There is a noticeable revival and renewal underway, on many levels. Ever since the conference Operette unterm Hakenkreuz (Operetta under the Swastika) at Staatsoperette Dresden in 2005 there has been a flood of publications about the political dimension of operetta, whether it is Boris von Haken's 2007 Der "Reichsdramaturg" Rainer Schlösser und die Musiktheater-Politik in der NS-Zeit or Christoph Domke's 2011 Unterhaltungsmusik und NS-Verfolgung, not to mention Matthias Kauffmann's monumental Operette im 'Dritten Reich': Musikalisches Unterhaltungstheater zwischen 1933 und 1945. Many researchers have also started utilizing letters, business correspondences and diaries for the first time for new biographies, e.g. Barbara Denscher with her 2017 'Werkbiografie' Der Operettenlibrettist Victor Léon. In many cases, though, researchers present novel facts but shy away from asking hard questions, e.g. Stefan Frey who writes about Leo Fall and the composer's erratic behavior and constant disappearances in the 2010 Leo Fall: Spöttischer Rebell der Operette, yet never wonders if such typical drug addiction behavior might not indicate that Fall and his wife were 'junkies.' It seems researchers still have some way to go in accepting that in a world of 'safe space' operetta the same ugly things happen as anywhere else, and that operetta composers can write brilliantly carefree waltzes and still be addicts.

The new research goes hand in hand with a new interest in shows beyond the post-war core repertoire of Fledermaus, Merry Widow and White Horse Inn. Barrie Kosky at Berlin's Komische Oper has been especially important in reviving the jazz operettas of the 1920s, bringing long forgotten titles back into circulation and thus showing that there are many aspects in these shows that can be of interest for future generations of operetta fans. Something that was also very evident in 2018 when the activist Gorki Theater in Berlin offered the Mischa Spoliansky/Marcellus Schiffer cabaret operetta Alles Schwindel and landed a hit. In a "Letter from Berlin" Irish Times correspondent Derek Scally wrote in January 2018:

After initial caution about the unfamiliar repertoire, [Barrie Kosky's] Berlin audiences now cannot get enough of these newold works drawn from a deep well of forgotten cultural memory. The latest revival from this source at Berlin's Gorki Theatre is Alles Schwindel (All's a Swindle), a sly political revue from 1931 using songs and scenes to mock both late-stage Weimar decadence and the rising fascist wave. [...] The Gorki Theatre's knock-out revival [...] involves a flimsy plot with its roots in deceptive lonely hearts 
ads, a conceit familiar to a young audience drawn from the Tinder/ selfie generation. They howl with delight [...]. Any similarities to today's Berlin hipsters is, of course, completely coincidental. ${ }^{43}$

Being able to relate to operetta stories is directly linked to the various 'safe space' functions the genre had in the past when it was a 'positive space' for sexual liberation and the breaking-up of gender norms, and for a self-ironic look at one's one position in society, whether it is as the user of lonely hearts ads or as someone who refuses to let anyone interfere with his or her personal freedom, like the Count de Morny. Such aspects are far more up-to-date for many younger audience members than the post-WW2 concept of operetta-as-tranquillizer.

Operetta once triggered half the world with outrage and moral shock tactics. And, arguably, the world's best operettas come from that time, including those by Franz von Suppé and Johann Strauss. So let's play and analyze them once more as outrageously as they were originally written and intended, which includes operettas from between World War I and II, pre and post 1933, putting these shows into a broad socio-historical context. And let's enjoy them as 'liberated' as most societies today are not. Because that is the true and lasting utopia of the genre.

\section{Bibliography}

Allen, Robert C. Horrible Prettiness: Burlesque and American Culture. Chapel Hill-London: University of North Carolina Press, 1991.

Anon. “France." The Daily News [London], January 30, 1867.

Anon. "Wiener Bilder. Der Prater." Illustrirte Zeitung [Vienna], May 21, 1881.

Baily, Leslie. The Gilbert \& Sullivan Book. London: Cassell \& Company Ltd., 1951.

Bovenschen, Silvia. Älter werden. Frankfurt a. M.: Fischer, 2013.

Bratby, Richard. "Operetta is serious business in Bad Ischl - and seriously glorious." The Spectator [spectatopr.co.uk], August 25, 2018. https://www.spectator.com.au/2018/o8/operetta-is-serious-businessin-bad-ischl-and-seriously-glorious/.

43 Derek Scally, "A new Berlin audience embraces its lost theatre past," Irish Times, January 6, 2018, https://www.irishtimes.com/news/world/europe/a-new-berlin-audience-embraces-its-lost-theatre-past-1.3346177. 
Fetscher, Caroline. "Das Phantasma des reinen Raums.” Tagesspiegel, May 8, 2018. https://www.tagesspiegel.de/politik/angst-vor-der-globalisierungdas-phantasma-des-reinen-raums/21258152.html.

Gänzl, Kurt. Emily Soldene: In Search of a Singer. Vol. 1. Wellington: Steele Roberts Ltd., 2007.

Herzog, Dagmar. Paradoxien der sexuellen Liberalisierung [Hirschfeld-Lectures series]. Göttingen: Wallstein Verlag, 2013.

Hohenegg, Franz von. Operettenkönige: Ein Wiener Theaterroman. Berlin: Hermann Laue Verlag, s. a.

Howell, William Dean. “The New Taste in Theatricals.” Atlantic Monthly, May 1869.

Jones, Robert. "Patience: Savoy Net Discussion. Oscar Wilde, Aestheticism and Effeminacy." Gilbert and Sullivan Archive. https://gsarchive.net/patience/discussion/wilde.html.

Kauffmann, Matthias. Operette im 'Dritten Reich'. Musikalisches Unterhaltungstheater zwischen 1933 und 1945 [Musik im 'Dritten Reich' und im Exil - Band 18]. Neumünster: von Bockel, 2017.

Kracauer, Siegfried. Jacques Offenbach und das Paris seiner Zeit. Frankfurt a.M.: Suhrkamp, 1994 [1. edition Amsterdam, 1937].

Lindhardt, Marion. Residenzstadt und Metropole: Zu einer kulturellen Topographie des Wiener Unterhaltungstheaters (1858-1918). Tübingen: Max Niemeyer Verlag, 2006.

Lindhardt, Marion, ed. Stimmen zur Unterhaltung. Operette und Revue in der publizistischen Debatte (1906-1933). Wien: Quodlibet, 2009.

Quissek, Heike. Das deutschsprachige Operettenlibretto: Figuren, Stoffe, Dramaturgie. Stuttgart, Weimar: J. B. Metzler 2012.

Rounding, Virginia. Grandes Horizontales: The Lives and Legends of Four Nineteenth-Century Courtesans. London: Bloomsbury, 2003.

Scally, Derek. "A new Berlin audience embraces its lost theatre past." Irish Times, January 6, 2018. https://www.irishtimes.com/news/world/ europe/a-new-berlin-audience-embraces-its-lost-theatre-past-1.3346177.

Schaller, Wolfgang, ed. Operette unterm Hakenkrez. Zwischen hoffähiger Kunst und "Entartung." Berlin: Metropol Verlag, 2007.

Senelick, Laurence. Jacques Offenbach and the Making of Modern Culture. New York: Cambridge University Press, 2017.

Senelick, Laurence. "Sexuality and Gender." In The Cultural History of Theatre in the Age of Empire, edited by Peter Marx, 77-96. London, Oxford, New York, New Delhi, Sydney: Bloomsbury, 2018. 
Steiner, Bertram Karl. "Operette und Existentialismus. Über ein schmerzstillendes Mittel.” In Das Land des Glücks. Österreich und seine Operetten, edited by Erik Adam and Willi Rainer, 17-24. Klagenfurt, Ljubljana, Wien: Hermagoras Verlag, 1997.

Strauss-Schom, Alan. The Shadow Emperor: A Biography of Napoléon III. New York: St. Martin's Press, 2018.

Traubner, Richard. Operetta: A Theatrical History. Abingdon-on-Thames: Routledge, 2003.

Williams, Carolyn. Gilbert and Sullivan: Gender, Genre, Parody. New York: Columbia University Press, 2011.

Zola, Émile. Nana. Translated by George Holden. London: Penguin Classics 1972. 